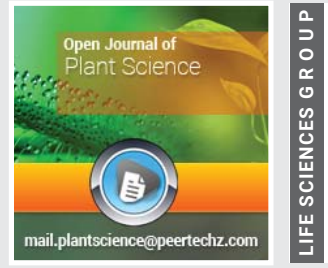

\title{
Response of maize phenology and grain yield to various nitrogen rates and plant spacing at Bako, West Ethiopia
}

Received: 27 November, 2019

Accepted: 23 December, 2019

Published: 24 December, 2019

*Corresponding author: Begizew Golla, Ethiopia Institute of Agricultural Research (EIAR), Bako National Maize Research Center (BNMRC), Ethiopia, Tel: 251912876351; E-mail: begizew03@yahoo.com

Keywords: BH 546; Nitrogen rate; Plant spacing; Yield https://www.peertechz.com

Check for updates

\section{Begizew Golla* and Desalegn Chalchisa}

Ethiopia Institute of Agricultural Research (EIAR), Bako National Maize Research Center (BNMRC), Ethiopia

\section{Abstract}

Maize hybrid responds differently to various $\mathrm{N}$ rates and plant spacing with changing in grain yield and phenological period to reflect the respond. A field experiment was conducted at Bako research farm in the year 2017 to determine the response of maize phenology and grain yield for various nitrogen fertilizer rates and plan spacing. The experiment was arranged in a Randomized Complete Block Design in factorial combination with three replications. Three plant spacing i.e. $20 \mathrm{~cm}, 30 \mathrm{~cm}$ and $40 \mathrm{~cm}$, with one row spacing of $75 \mathrm{~cm}$ and six nitrogen rates i.e. $0 \mathrm{~kg} \mathrm{ha}^{-1}, 23 \mathrm{~kg} \mathrm{ha}^{-1}, 46 \mathrm{~kg} \mathrm{ha}^{-1}, 69 \mathrm{~kg} \mathrm{ha}^{-1}, 92 \mathrm{~kg} \mathrm{ha}^{-1}$ and $115 \mathrm{~kg} \mathrm{ha}^{-1}$ were assigned to the experimental plot by factorial combinations. The results showed that reduction in plant spacing and nitrogen starvation resulted delaying to attain $50 \%$ tasseling and silking while it speeding up maturity period. Maximum grain yield (10,207.8 kilo gram per hectare) obtained under the narrowest plant spacing (20 centimeters) with application of the highest rate of nitrogen (115 kilo gram nitrogen per hectare). This yield result surpassed by $8.9 \%$ compared to the standard check. The experiment indicated an increasing trend of grain yield with increasing $\mathrm{N}$ rate and decreasing plant spacing, so further increasing of $\mathrm{N}$ rates and reducing plant spacing might further increased the grain yield.

\section{Introduction}

Maize (Zea mays L.) is one of the most important cereal crops, widely grown in most parts of the world for various benefits of human beings. It is used as food, feed and raw materials for some industrial products [1]. In Ethiopia more than 9 million smallholder households grow maize more than any other crops at present [2]. It is one of the most strategic crops selected to achieve food security in this country [3]. Considering its important in food security, extensive research work is carrying out every year for further improvement its grain yield [4-6]. Nevertheless its productivity is still at a low profile (3.2t/ha), because of poor agronomic practices, lack of improved seeds and climate variability [7]. Plant population and nutrient management are among key agronomic factors which determine growth, phenology and yield of maize and other field crops.

Maize is very sensitive to changes in plant density. Grain yield of maize increased with increased plant density up to optimum and declines when plant density is increased further
[8]. High plant population influences synchrony of flowering, delay ear initiation, slow silk development, aggravated abortion of recently fertilized ovaries, and promote barrenness and the production of nubbin ears that leading to substantial reduction of final grain yield of maize [9]. Plant reduction per unit area prevents maximum usage of production parameters while excessive density can increase the competition and decrease the yield [10].

Nitrogen and plant population are considered as the most important factors affecting flowering (days to tasseling and silking), maturity and grain yield performance of maize [11]. Limitation in nitrogen nutrient and crowded stress may delay developmental events and decrease both spikelet number and silk extrusion, contributing to reduce the number of spikelet that can be fertilized through coincidence of pollen shed [12]. Higher plant density resulted asynchronous flowering [13]. An asynchronous flowering may limit grain production per ear due to lack of pollen, loss of silk receptivity or early kernel abortion caused by the dominance of early formed ovaries from the base of the ear on the late formed from the tips [14]. Maize sown in 
closer plant spacing subjected to high competition for various growth factors that resulted delayed in tasseling, silking and physiological maturity period [15-17]. However Ketema, et al., [18], reported longest day to attain $90 \%$ physiological maturity under wider spacing.

Maize is an exhaustive feeder of nutrients; the chemical fertilizer especially nitrogen fertilizer is universally accepted as a key component to high maize yield [11], and if deficiency occurs at tasseling and silking stages it may lead to virtual crop failure. Application of nitrogen as well as increase in its rate induced earliness of tasseling and silking stages [19-22]. In contrast to tasseling and silking stages, increasing nitrogen rate application significantly increased number of days to physiological maturity $[11,16,21,23]$.

Crop yield tend to increase with increasing the nitrogen rate. Grain yield of maize increased significantly with increasing in $\mathrm{N}$ rate [11,24-27]. $\mathrm{N}$-fertilization provided sufficient nutritional requirements for the maize plants to rapidly grow and hence promoted its grain production [6].

Thus in order to obtain maximum yield per unit area application of adequate nitrogen fertilizer rate with appropriate plant density is crucial task especially for maize crop which is high influenced by these factors.

Considering the above facts, the present study was undertaken to elucidate the effects of nitrogen rates and plant spacing on phenology and grain yield of maize under main cropping season.

\section{Materials and methods}

\section{Description of experimental site}

The experiment was conducted at Bako research site located at $9^{\circ} 06^{\prime} \mathrm{N}$ and $37^{\circ} 09^{\prime} \mathrm{E}$, with altitude of 1650 m.a.s.l, in western Ethiopia, in the year 2017. The soils of the area are dominantly nitisol. The site represents mid-altitude subhumid agro ecology. The total annual rain fall during 2017 season was $1598.0 \mathrm{~mm}$. The cite had mean minimum, mean maximum and average annual temperatures of $12.8^{\circ} \mathrm{C}, 29.0^{\circ} \mathrm{C}$ and $20.9^{\circ} \mathrm{C}$ respectively and humidity ranged from 46 to $57 \%$ in the year of 2017.

\section{Experimental materials}

Intermediate maturing maize hybrid $\mathrm{BH} 546$ was used for the study. This hybrid gives $8500-9500$ and $5500-7000 \mathrm{~kg} \mathrm{ha}^{-1}$ grain yield on-station and on-farm experiments, respectively BNMRC, 2014. Nitrogen fertilizer in the form of urea $(46 \% \mathrm{~N})$ and phosphorous fertilizer in the form of Triple Superphosphate $\left(46 \% \mathrm{P}_{2} \mathrm{O}_{5}\right)$ were used for the experiment.

\section{Treatments and experimental design}

The treatments comprised of six rates of nitrogen ( $0 \mathrm{~kg} \mathrm{~N}$ ha $^{-1}$, 23kg N ha-1, $46 \mathrm{~kg} \mathrm{~N} \mathrm{ha}^{-1}, 69 \mathrm{~kg} \mathrm{~N} \mathrm{ha}^{-1}, 92 \mathrm{~kg} \mathrm{~N} \mathrm{ha}^{-1}$ and $115 \mathrm{~kg}^{-1}$ $\mathrm{N} \mathrm{ha}^{-1}$ ), fixed inter row spacing of $75 \mathrm{~cm}$, and three intra row spacing of $20 \mathrm{~cm}, 30 \mathrm{~cm}$ and $40 \mathrm{~cm}$. The treatment $(75 \times 30 \mathrm{~cm}$ spacing with 92 $\mathrm{kg} \mathrm{N} \mathrm{ha-1}^{-1}$ ) was used as a standard check whereas okg $\mathrm{N} \mathrm{ha}^{-1}$ was used as negative control. The experiment was arranged in Randomized Complete block Design (RCBD) in factorialcombination with three replications. The gross plot size was $4.8 \mathrm{~m} \times 3.0 \mathrm{~m}\left(14.4 \mathrm{~m}^{2}\right)$ with row length of $4.8 \mathrm{~m}$, and net plot size $4.8 \mathrm{~m} \times 1.5 \mathrm{~m}\left(7.2 \mathrm{~m}^{2}\right)$ was used for harvesting. The treatments were randomly assigned to the experimental unit within a replication. The replications were separated by $2 \mathrm{~m}$ wide space.

\section{Experimental procedures}

Land prepared, three times, using tractor plough from March to May 2017. Planting was done in June 2017. Full dose of phosphate fertilizer in the form of Triple Superphosphate at rate of $69 \mathrm{~kg}_{2} \mathrm{O}_{5}$ ha $^{-1}$ was applied uniformly to all plots at sowing time. Half dose of $\mathrm{N}$ fertilizer for each treatment was applied at sowing time and the remaining half dose of $\mathrm{N}$ fertilizer was applied four weeks after sowing. Others crop management practices were applied uniformly to all plots as per the experience of the farm. Finally, maize plants were harvested at harvest time ,in the central net plot area, for the analysis.

\section{Crop data collection}

Days to $50 \%$ tasseling Days were counted from sowing to the day when $50 \%$ of the maize plants shed their tassels in each plot. Days to $50 \%$ silking It was recorded as the number of days require from planting to when $50 \%$ of the maize plant showed extrusion of silks in each plot. Both days to $50 \%$ tasseling and silking were determined by similar way of visual observation. Physiological maturity days: The days of physiological maturity were recorded when $90 \%$ of plants formed black layer at the base of the kernel (at the point where the kernel attached with the cob). Grain yield ( $\mathrm{kg} \mathrm{ha}^{-1}$ ) was calculated from total number of plants in the net plot by adjusting the field weight and grain moisture immediately.

\section{Statistical analysis}

Analyses of variances for the data recorded were conducted using the SAS version 9.3. Least Significant Difference (LSD) test $(5 \%)$ was used for mean separation if the analysis of variance indicated the presence of significant treatment differences.

\section{Results and discussion}

\section{Effect of various nitrogen levels on flowering date of maize}

The analysis of variance revealed highly significant $(\mathrm{P}<0.01)$ effects of applied $\mathrm{N}$ rates on the days to $50 \%$ tasseling and significant $(\mathrm{P}<0.05)$ effect on the days to $50 \%$ silking of maize (Table 1). However, the interaction of $\mathrm{N}$ rates and plant spacing was not significant.

The tasseling period became increased as the nitrogen level decreased and the maximum days to $50 \%$ tasseling (82.44) were recorded under okg $\mathrm{N} \mathrm{ha}^{-1}$, but it was statistically similar with days to $50 \%$ tasseling (81.78) recorded under $23 \mathrm{~kg} \mathrm{~N} \mathrm{ha}^{-1}$ 
Table 1: Mean square values of ANOVA for Grain yield and phenological parameters of maize affected by nitrogen rates and plant spacing.

\begin{tabular}{|c|c|c|c|c|c|}
\hline & \multicolumn{2}{|c|}{} & \multicolumn{2}{|c|}{ Mean Square } & \\
\hline Source & DF & DT & DS & DPM & GY \\
\hline REP & 2 & 2.056 & $4.796^{\text {ns }}$ & $5.167^{\star}$ & $831931.70^{\star *}$ \\
\hline NR & 5 & $3.022^{\star \star}$ & $4.785^{\star}$ & $3.911^{\star}$ & $14263759.68^{* *}$ \\
\hline PS & 2 & $2.389^{\star}$ & $15.130^{\star *}$ & $7.722^{\star *}$ & $3704822.56^{* \star}$ \\
\hline NR*IRS & 10 & $0.144^{\text {ns }}$ & $0.174^{\text {ns }}$ & $0.300^{\text {ns }}$ & $642658.02^{\star *}$ \\
\hline Error & 34 & 0.644 & 1.639 & 1.382 & 113349.97 \\
\hline CV & & 0.985 & 1.530 & 0.760 & 4.271 \\
\hline
\end{tabular}

Where, DF: Degrees of Freedom; DT: Days to 50\% Tasseling; DS: Days to 50\% Silking; PMD: Days to $90 \%$ Physiological Maturity; GY: Grain Yield; PS: Plant Spacing; NR: Nitrogen Rate; ns: non-significant; *: significantly different at $5 \%$ and **: significantly different at $1 \%$ level significant.

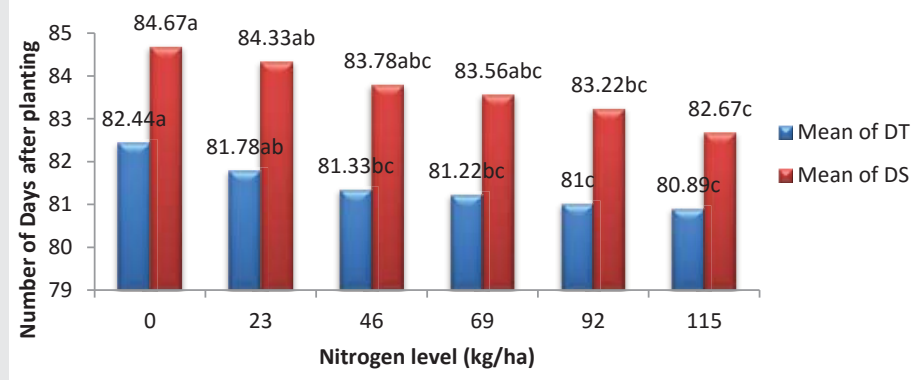

Figure 1: Effect of various nitrogen level on flowering date of maize at Bako in $2017 / 2018$ croping season.

Where, DA is days to tasseling and DS is days to silking. Mean followed by the same letter in the bar graph are not significantly different $(P<0.05)$.

application (Figure 1). The minimum days to $50 \%$ tasseling was obtained under application of $115 \mathrm{~kg} \mathrm{~N} \mathrm{ha}^{-1}$. However, statistically similar results were also recorded under application of 46, 69 and $92 \mathrm{~kg} \mathrm{~N} \mathrm{ha}^{-1}$ (Figure 1). But the tasseling period became shortest numerically as the nitrogen level increased. In addition to early tasseling, the plots received higher $\mathrm{N}$ rate were uniformly flowered, while in the lowest nitrogen rate the maize crop remained delay to attained $50 \%$ tasseling even though a very few plants tasseled earlier.

Like that of days to tasseling, days to silking delayed with decreasing nitrogen level and increasing in plant density, which accompany with high competition. Mean values for nitrogen rates showed that days to $50 \%$ silking delayed by 2 days in a treatment with no $\mathrm{N}$ application compared to a treatment that fed with $115 \mathrm{~kg} \mathrm{~N}^{-1}$ (Figure 1). Thus the maximum days to $50 \%$ silking (84.67) were recorded in a plot with no $\mathrm{N}$ application. However, it was statistically similar with days to $50 \%$ silking recorded under a treatment of 23,46 and $69 \mathrm{~kg} \mathrm{ha}^{-1} \mathrm{~N}$-rates. The minimum days to $50 \%$ silking (82.67) were obtained under maximum $\mathrm{N}$ rate $\left(115 \mathrm{~kg} \mathrm{~N} \mathrm{ha}^{-1}\right)$ But statistically similar result were also obtained under application of 46, 69 and $92 \mathrm{~kg} \mathrm{~N} \mathrm{ha}^{-1}$. However, there was a decreasing trend in days to $50 \%$ silking with increasing in nitrogen rates.

\section{Effect of plant spacing on flowering date of maize}

The analysis of variance showed that a significant $(\mathrm{P}<0.05)$ effects and highly significant $(\mathrm{P}<0.01)$ effect of plant spacing on the days to $50 \%$ tassing and days to $50 \%$ silking respectively
(Table 1). However, the interaction of $\mathrm{N}$ rates and plant density was not significant (Table 1). The days to $50 \%$ tasseling and silking tend to increasing with decreasing plant spacing. The maximum days to $50 \%$ tasseling (81.83) were recorded under the lowest plant spacing $(20 \mathrm{~cm})$, while the lowest day to $50 \%$ tasseling (81.11) were noted under the highest plant spacing (40). However the days to $50 \%$ tasseling obtained under medium plant spacing $(30 \mathrm{~cm})$ was statistically similar to both days to $50 \%$ tasseling obtained under $20 \mathrm{~cm}$ and $40 \mathrm{~cm}$ plant spacing (Figure 2).

Similarly maximum number of days to $50 \%$ silking (84.72) were recorded in a plot where the maize sown at plant spacing $20 \mathrm{~cm}$ which corresponding to 66,666 plant ha-1 $^{-1}$ while the minimum days to $50 \%$ silking (82.94) were observed at the half plant density, the widest plant spacing of $40 \mathrm{~cm}$. The number of days to $50 \%$ silking for intra row spacing of $30 \mathrm{~cm}$ were in between these two plant spacing (83.44) (Figure 2) which indicates significant increasing trend in days to $50 \%$ silking with the increasing in plant spacing.

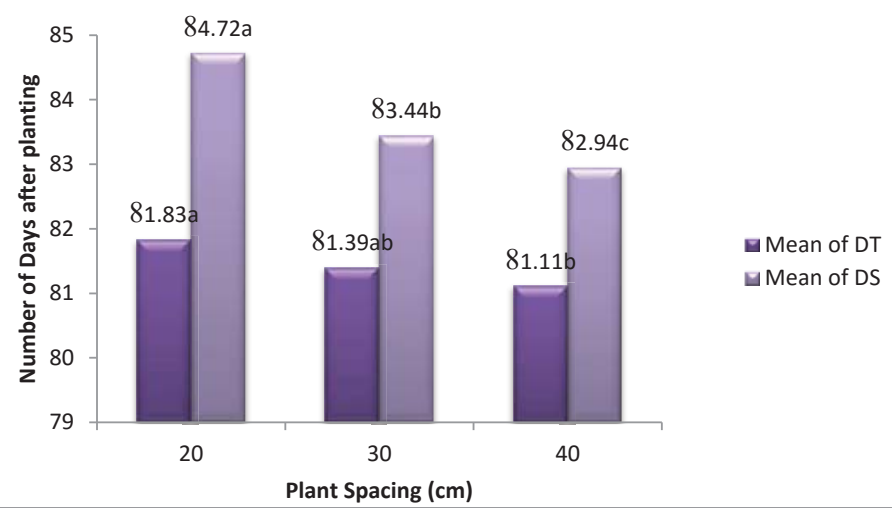

Figure 2: Effect of plant spacing on flowerong date of maize at Bako in 2017/2018 croping season.

Where, DA is days to anthesis and DS is days to silking. Mean followed by the same letter in the bar graph are not significantly different $(P<0.05)$

\section{Effect of various nitrogen levels on physiological matu- rity date of maize}

The effects of nitrogen rates and plant spacing on $90 \%$ physiological maturity were significant but their interaction had not shown any significant effect. Increasing nitrogen rate significantly $(\mathrm{p}<0.05)$ increased number of days to physiological maturity (Table 1). The maximum days to attained $90 \%$ physiological maturity were recorded under maximum $\mathrm{N}$ rate $\left(115 \mathrm{~kg} \mathrm{~N} \mathrm{ha}^{-1}\right)$, but statistically similar days to $90 \%$ maturity were recorded under application 46,69 and $92 \mathrm{~kg} \mathrm{~N} \mathrm{ha}^{-1}$. The shortest day to attained $90 \%$ physiological maturity was obtained under no $\mathrm{N}$ application, but it was not significantly different from days of $90 \%$ physiological maturity recorded under treatments those received 23,46 and $69 \mathrm{~kg} \mathrm{~N}$ $\mathrm{ha}^{-1}$ (Figure 3). However, as the nitrogen rates increased, the days to physiological maturity were also numerically increased.

\section{Effect of plant spacing on physiological maturity date of maize}

The maturity of the crop was also affected by the plant 
spacing $(\mathrm{P}<0.01)$ (Table 1) The maize crop that was planted in plant spacing of $20 \mathrm{~cm}$ matured earlier than that planted in a wider plant space $(40 \mathrm{~cm})$. The days to $90 \%$ maturity was increased with increasing plant spacing, but with no significant difference when plan spacing increased from $20 \mathrm{~cm}$ to $30 \mathrm{~cm}$. The number of days required to attain $90 \%$ maturity process were $154.22,154.61$ and 155.50 days for $20 \mathrm{~cm}, 30 \mathrm{~cm}$ and $40 \mathrm{~cm}$ plant spacing respectively (Figure 4).

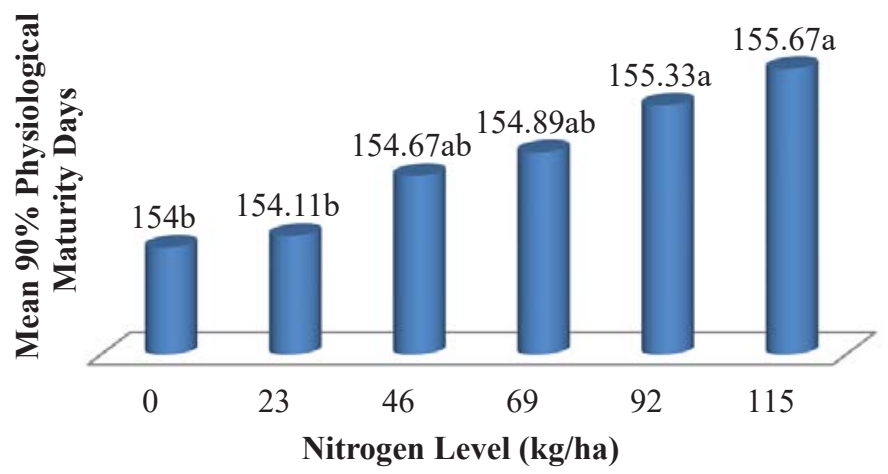

Figure 3: Effect of nitrogen level on Physiological maturity of maize at Bako in 2017/2018 main croping season.

Mean followed by the same letter in the bar graph are not significantly different $(P<0.05)$

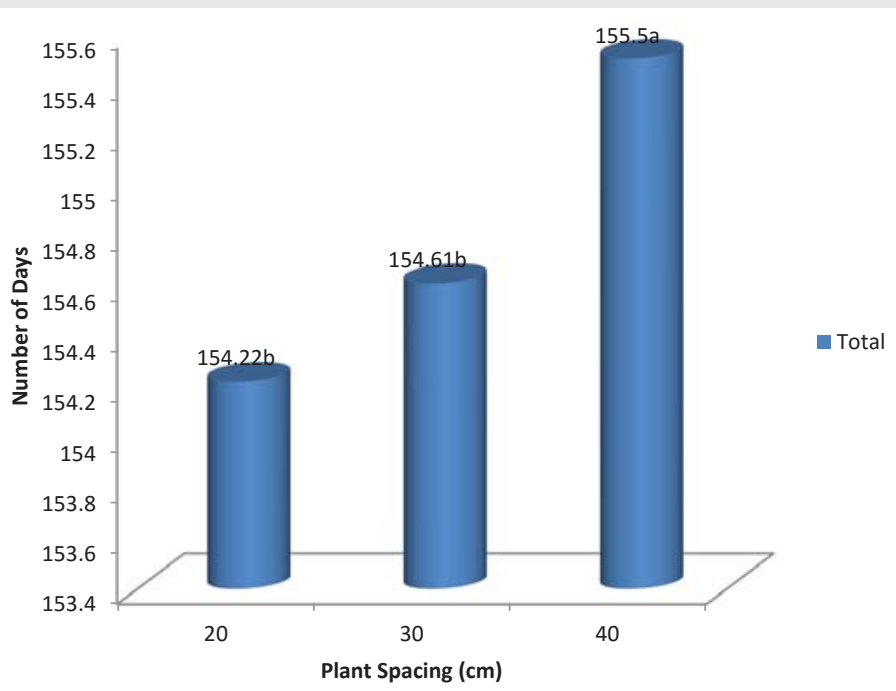

Figure 4: Effect of Plant Spacing on maturity Date of Maize at Bako in 2017/2018 main croping season.

Mean followed by the same letter in the bar are not significantly different $(P<0.05)$.

\section{Effect of different nitrogen rates and plant spacing on grain yield of maize}

The ultimate goal of crop production is increasing economic yield. Both of the main effects (rate of nitrogen and plant spacing) and their interaction had a significant $(\mathrm{P}<0.01)$ effect on grain yield of maize (Table 1).

Maximum grain yield $\mathrm{ha}^{-1}(10207.80 \mathrm{~kg})$ was achieved at the plant spacing of $20 \mathrm{~cm}$ with the application of $115 \mathrm{~kg} \mathrm{~N} \mathrm{ha}^{-1}$ but it was statistically similar with $(9886.90 \mathrm{~kg})$ that produced under the rate of $92 \mathrm{~kg} \mathrm{~N} \mathrm{ha}^{-1}$ application for the same intra row spacing $(20 \mathrm{~cm})$. The minimum grain yield (6358.80) was obtained under okg $\mathrm{N} \mathrm{ha}^{-1}$ at $20 \mathrm{~cm}$ plan spacing, but statistically similar grain yield were obtained under application of 0 and $23 \mathrm{~kg} \mathrm{~N} \mathrm{ha}^{-1}$ at all plant spacing including $46 \mathrm{~kg} \mathrm{~N} \mathrm{ha}^{-1}$ application in case of $40 \mathrm{~cm}$ intra row spacing (Table 2 ).

Table 2: Effect of different nitrogen rates and plant spacing on grain yield of maize during 2017/2018 cropping season.

\begin{tabular}{|c|c|c|c|c|c|c|}
\hline $\begin{array}{c}\text { Intra row } \\
\text { spacing (cm) }\end{array}$ & & & & \multicolumn{2}{|c|}{ N rate $\left.\mathbf{( k g h a - 1}^{-1}\right)$} & \\
\hline & 0 & 23 & 46 & 69 & 92 & 115 \\
\hline 20 & $6358.80^{\mathrm{h}}$ & $6392.00^{\mathrm{h}}$ & $7585.90^{\text {ef }}$ & $8709.90^{\mathrm{d}}$ & $9886.90^{\mathrm{ab}}$ & $10207.80^{\mathrm{a}}$ \\
\hline 30 & $6619.40^{\mathrm{h}}$ & $6711.00^{\mathrm{h}}$ & $7525.50^{\mathrm{fg}}$ & $8794.00^{\text {cd }}$ & $9373.80^{\mathrm{bc}}$ & $9544.2^{\mathrm{b}}$ \\
\hline 40 & $6519.80^{\mathrm{h}}$ & $6591.10^{\mathrm{h}}$ & $6906.50^{\mathrm{gh}}$ & $7711.90^{\text {ef }}$ & $8234.20^{\text {de }}$ & $8202.7^{\text {de }}$ \\
\hline
\end{tabular}

LSD (0.05) N $\times$ IRS $=648.3 \quad$ CV $(\%)=4.271$

Means followed by the same letter within column are not significantly different $(P<0.05)$

\section{Discussion}

The tasseling and silking date of maize increased with decreasing in nitrogen rate. The delaying of flowering date in response $\mathrm{N}$ starvation has been previously acknowledged $[8,11,19,22]$, but this research is the first to report the effect of $\mathrm{N}$ rate on uniformity of tasseling. With increase in $\mathrm{N}$ rate the availability of nutrients in the soil increased. This condition reduced intra-specific competition pressure within the stands which may lead to uniform flowering, whereas $\mathrm{N}$ starvation promote the appearance of individual plants with different abilities to capture scarce resources and eventually corrugated their tasseling period. Brady (1984) indicated that in addition to its direct nutritional role to the plant, the optimum amounts of some other elements in the soil cannot be utilized efficiently if nitrogen is deficient. However, there were researchers who reported results opposite to ours. Imran, et al., [15], stated that increasing nitrogen level consistently increased days to $50 \%$ tasseling due to prolonging the vegetative growth period.

Like that of days to tasseling, days to silking were delayed with $\mathrm{N}$ starvation and high population density, which accompany with high competition. This decreasing in silking period in response to increasing in $\mathrm{N}$ rate might be attributing to rapidness in growth period and promoting silk extrusion. These results are in consistent with the finding of Shrestha [11], who observed that the earlier days to tasseling at the treatment which received the more rate of nitrogen. Similarly, Dawadi and Sah [21] and Jassal, et al., [22]. Reported that application of nitrogen as well as increase in its rate induced earliness of tasseling and silking stages. However, there has been some controversy regarding the phenological parameters of maize. Imran, et al., [15], Sharifi, and Namvar [16], stated that maize took more time to tasseling and silking in plots that received the highest rate of $\mathrm{N}$.

Maize flowering date increased with decreasing plant spacing. This might be due to that higher plant densities under narrow plant spacing, induce competition among crop plants 
for different growth resources such as light, nutrient, water and air. It is a general truth that competition among crop plants for different growth limiting resources raised at plant stand closed to each other, and this might have slowed the pace of phenological development which ultimately delayed the emergence of tasseling and silking. This increase in tasseling and silking period in response to narrow intra row spacing (higher plant density) has been confirmed by the previous findings of Shrestha[11], Imran, et al., [15], Sharifi and Namvar [16], Khan, et al., [17].

Physiological maturity days of maize increased with increased in nitrogen rate. Higher nitrogenous fertilizer delayed the senescence of leaves and plant remained more prolong as green stage this can increase the days required to attained physiological maturity. Similar results have been found by many other researchers among whom, Shrestha [11], Sharifi and Namvar [16] and Anwar, et al., [23], reported that the process of physiological maturity delayed with increasing the rate of $\mathrm{N}$ application. Dawadi and Sah [21], stated that increasing nitrogen level from $120 \mathrm{kgha}^{-1}$ to $200 \mathrm{kgha}^{-1}$ decreased the tasseling, silking and anthesis-silk interval but increased the physiological maturity and seed fill duration.

Increasing in plant density decreased days to physiological maturity. This might be due to competition among crop plants at closer plant spacing for different resources (light, moisture and nutrients) that might have reduced the rate of phenological development that ultimately reduced maturity period. These results coincided with the findings of Ketema, et al., [18], who observed that the longest duration (106.1) days to $90 \%$ physiological maturity at the widest plant spacing of $30 \mathrm{~cm}$ and the shortest (103.6) days at the narrowest plant spacing of $20 \mathrm{~cm}$. However Shrestha [11] and Imran, et al., [15], were reported Reverse results, which indicated those days to $90 \%$ physiological maturity increase with increasing plant population.

In general, the grain yield ha-1 was increased with the increase in $\mathrm{N}$ rate and with decreasing in plant spacing. However, in the wider plant spacing $(40 \mathrm{~cm})$, increase of nitrogen rate above $92 \mathrm{~kg} \mathrm{Nha}^{-1}$ was not effective in increasing the grain yield which can be attributed to the extra loss of nitrogen through leaching from root zone. The mean grain yield ha-1 was increased by $16.35 \%$ and $24.44 \%$ with reducing plant spacing from $40 \mathrm{~cm}$ to 30 and $20 \mathrm{~cm}$ under highest $\mathrm{N}$ rate $\left(115 \mathrm{~kg} \mathrm{Nha}^{-1}\right)$ respectively.

Compared to the standard control of the plant spacing $30 \mathrm{~cm}$ ( 44444 plant ha-1) with the application of $92 \mathrm{~kg} \mathrm{Nha}^{-1}$, the mean grain yield was increased by $834 \mathrm{~kg} \mathrm{ha}^{-1}$ or $8.90 \%$ when the maize hybrid sown at plant spacing of $20 \mathrm{~cm}$ with application 115kg Nha-1.

In this experiment, the grain yield per unit area had a multiplicative trend, and application of the highest $\mathrm{N}$ rate $\left(115 \mathrm{~kg} \mathrm{~N} \mathrm{ha}^{-1}\right)$ at the closer plant spacing $(20 \mathrm{~cm})$ was produced the maximum yield, although statistically similar yield under application of $92 \mathrm{~kg} \mathrm{~N} \mathrm{ha}^{-1}$ in the same plant spacing was obtained. So, these results indicates an opportunity to increase grain yield with higher $\mathrm{N}$ application and lowest plant spacing beyond $115 \mathrm{~kg} \mathrm{Nha}^{-1}$ and $20 \mathrm{~cm}$ intra row spacing.

The positive relationship between yield and narrow plant spacing was due to the high number of high number of plants per unit area. The increased in maize grain yield under decreased spacing might be due to efficient utilization of available resources (nutrient water and light). Farnia, et al., [10], stated that plant deficit per unit area prevents maximum usage of production parameters while excessive density can increase the competition and decrease the yield.

Higher grains yield at higher nitrogen levels might be due to the lower competition for nutrient and positive effect of $\mathrm{N}$ on plant growth and coincide synchrony of male and female flowering.

These results are in line with that reported by of Gözübenli [8], Shrestha [11], Sharifi and Namvar [16]; Anwar, et al., [23].

\section{Conclusion}

The results obtained in this experiment showed that reduction in plant spacing and nitrogen starvation resulted delaying to attain $50 \%$ tasseling and silking while it speeding up maturity period. Maize hybrid $\mathrm{BH}-546$ produced the maximum grain yield when the hybrid was sown at $20 \mathrm{~cm}$ plant spacing with application of $115 \mathrm{~kg} \mathrm{~N} \mathrm{ha}^{-1}$, but application of $92 \mathrm{~kg} \mathrm{~N} \mathrm{ha}^{-1}$ at the same plant spacing $(20 \mathrm{~cm})$ was also produce similar result. Furthermore the experiment was indicated a multiplicative trend of grain yield with increasing $\mathrm{N}$ rate and decreasing plant spacing, so further modification of $\mathrm{N}$ rates up ward and plant spacing down ward might further increased the grain yield

\section{Acknowledgement}

We gratefully acknowledge the Ethiopia Institute of Agriculture Research (EIAR) for full funding of required budget to do this research work. Our thanks are also extended to all staff of Bako National and Regional research Centers for their invaluable help and for allowing us to use the facilities and for their moral as well as physical support during the whole experimental period.

\section{References}

1. Ranum P, Peña-Rosas JP, Garcia-Casal MN (2014) Global maize production, utilization, and consumption. Ann N Y Acad Sci 1312: 105-112. Link: http://bit.ly/3aubuFk

2. Abate $T$, Shiferaw B, Menkir A, Wegary D, Kebede $Y$, et al. (2015) Factors that transformed maize productivity in Ethiopia. Food Security 7: 965-981. Link: http://bit.ly/369yru9

3. Demissie G, Tefera T, Tadesse A (2008) Importance of husk covering on field infestation of maize by Sitophilus zeamais Motsch (Coleoptera: Curculionidea) at Bako, Western Ethiopia. Afr J Biotechnol 7. Link: http://bit.ly/2vbuskd

4. Tolessa B, Ransom JK (1993) Proceedings of the first national maize workshop of Ethiopia. National Maize Workshop of Ethiopia (1 ${ }^{\text {st. }}$ 1992: Addis Ababa, Ethiopia). Link: http://bit.ly/38wQBYB

5. Nigussie M, Tanner D, Twumasi-Afriyie S (2002) Enhancing the Contribution of Maize to Food Security in Ethiopia: Proceedings of the Second National Maize Workshop of Ethiopia: 12-16 November 2001, Addis Ababa, Ethiopia. CIMMYT. Link: http://bit.ly/2Rux0B6 
6. Khan N, Khan NW, Khan IA (2012) Integration of nitrogen fertilizer and herbicides for efficient weed management in maize (Zea mays) crop. Sarhad $J$ Agric 28: 457-463. Link: http://bit.ly/2GaOkYy

7. Alemu D, Yirga C, Bekele A, Tesfaye A (2014) Situation and Outlook of Maize in Ethiopia. Ethiopian Institute of Agricultural Research. Link: http://bit.ly/2v8XDEo

8. Gözübenli $\mathrm{H}$, Konuskan $\mathrm{O}$ (2010) Nitrogen dose and plant density effects on popcorn grain yield. Afr J Biotechnol 9: 3828-3832. Link: http://bit.ly/30GZZpu

9. Sangoi L (2001) Understanding plant density effects on maize growth and development: an important issue to maximize grain yield. Ciência rural 31 159-168. Link: http://bit.ly/2uhMDnO

10. Farnia A, Mansouri M, Farnia A, Branch B (2015) Study on Morphological Characteristics of Maize (Zea mays L.) Cultivars under Different Plant Densities. Indian J Nat Sci 5. Link: http://bit.ly/2TII8NN

11. Shrestha J (2013) Effect of nitrogen and plant population on flowering and grain yield of winter maize. Sky J Agric Res 2: 64-68.

12. Jacobs BC, Pearson CJ (1991) Potential yield of maize, determined by rates of growth and development of ears. Field Crops Res 27: 281-298. Link: http://bit.ly/38nZkvW

13. Amanullah K, Khalil RA, Shad K (2009) Plant density and nitrogen effects on maize phenology and grain yield. Journal of plant nutrition 32: 246-260. Link: http://bit.ly/2RAAB0z

14. Cárcova J, Otegui ME (2001) Ear temperature and pollination timing effects on maize kernel set. Crop scie 41: 1809-1815. Link: http://bit.ly/3aqwmgJ

15. Imran S, Arif M, Khan A, Khan MA, Shah W, et al. (2015) Effect of nitrogen levels and plant population on yield and yield components of maize. Adv Crop Sci Tec 1-7. Link: http://bit.ly/2ummi8c

16. Sharifı RS, Namvar A (2016) Plant density and intra-row spacing effects on phenology, dry matter accumulation and leaf area index of maize in second cropping. Biologija 62: 46-57. Link: http://bit.ly/2v1s4w2

17. Hayat Z, Khalil SK, Iqbal A, Ullah I, Ali M, et al. (2017) Nitrogen Doses and Plant
Density Affect Phenology and Yield of Sweet Corn. Fresenius Environmental Bulletin 26: 3809-3815. Link: http://bit.ly/2NKBhQ1

18. Ketema B, Jemal A, Hassen I (2017) Effect of Intra-row Spacing and In-situ Moisture Conservation on Yield Components and Yield of Maize (Zea mays L.) at Jigjiga, Eastern Ethiopia (Doctoral dissertation).

19. Tollenaar M, Aguilera A, Nissanka SP (1997) Grain yield is reduced more by weed interference in an old than in a new maize hybrid. Agronomy J 89: 239246. Link: http://bit.ly/36bQYGc

20. Gökmen S, Sencar Ö, Sakin MA (2001) Response of popcorn (Zea mays everta) to nitrogen rates and plant densities. Turkish J Agricul Forestry 25 15-23. Link: http://bit.ly/2RczMMF

21. Dawadi DR, Sah SK (2012) Growth and yield of hybrid maize (Zea mays L.) in relation to planting density and nitrogen levels during winter season in Nepal. Tropical Agricultural Research 23. Link: http://bit.ly/36eJP89

22. Jassal RK, Kang JS, Singh H, Singh T (2017) Growth, Phenology and Seed Yield of Fodder Maize in Relation to Different Planting Methods and Nitrogen Levels. Int J Curr Microbiol App Sci 6: 1723-1735. Link: http://bit.ly/3aq1YDr

23. Anwar S, Ullah W, Islam M, Shafi M, Iqbal A, et al. (2017) Effect of nitrogen rates and application times on growth and yield of maize (Zea mays L.). Pure Appl Biol 6: 908-916. Link: http://bit.ly/2ugPkpy

24. Dahmardeh M (2011) Effect of plant density and nitrogen rate on PAR absorption and maize yield. Am J Plant Physiol 6: 44-49. Link: http://bit.ly/2ueJHbr

25. Sharifai Al, Mahmud M, Tanimu B, Abubakar IU (2012) Yield and Yield componemts of extra early maize (zea mays L.) as influenced by intra-row spacing, nitrogen and poultry manure rates. Bayero J Pure Appl Sci 5: 113-122. Link: http://bit.ly/38pGynV

26. Azam S, Ali M, Amin M, Bibi S, Arif M (2007) Effect of plant population on maize hybrids. J Agricul Biologic Sci 2: 104-111. Link: http://bit.ly/2v3Qmpb

27. Sharifi RS, Namvar A (2016) Effects of time and rate of nitrogen application on phenology and some agronomical traits of maize (Zea mays L.). Biologija 62 Link: http://bit.ly/30E27yx
Discover a bigger Impact and Visibility of your article publication with Peertechz Publications

Copyright: () 2019 Golla B, et al. This is an open-access article distributed under the terms of the Creative Commons Attribution License, which permits unrestricted use, distribution, and reproduction in any medium, provided the original author and source are credited. 